
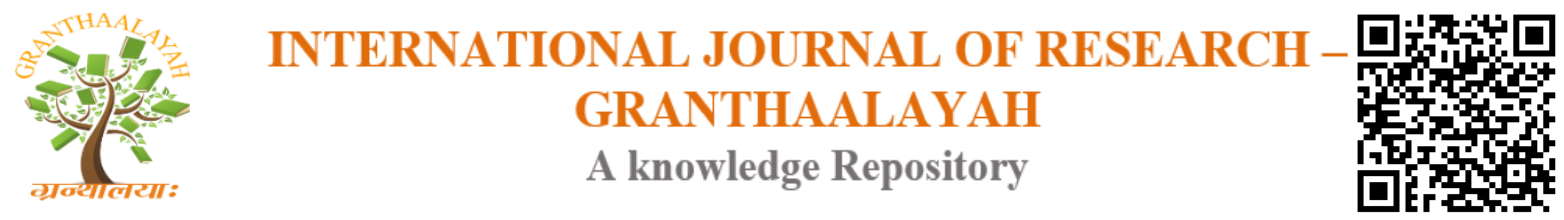

Science

\title{
REVIVING ART FORMS OF NIRONA-THROUGH ARCHITECTURE
}

\author{
Sejal Selwadiya *1, Ar. Soma A Mishra ${ }^{* 2}$, Kavya Trivedi ${ }^{* 3}$ \\ ${ }^{*} 1, * 2,{ }^{*}$ SDPS College of Architecture, India
}

\begin{abstract}
This research is subjected to the documentation of Nirona, in Kutch, Gujarat. Nirona is web of various art forms- Rogan painting, copper bell, lacquer art, leather art, Weaving, practiced at one place, making it culturally very rich. Though it is blessed with a bunch of art forms, it is still facing survival problems. Thus, it is getting at the verge of extinction. This research aims at documenting these art forms and understanding the reason behind its declination. Also, architectural contributions for their survival and upliftment are analyzed and based on that new suggestions are made.
\end{abstract}

Keywords: Architecture; Art and Crafts; Nirona; Rogan Painting; Copper Bell.

Cite This Article: Sejal Selwadiya, Ar. Soma A Mishra, and Kavya Trivedi. (2018). "REVIVING ART FORMS OF NIRONA-THROUGH ARCHITECTURE." International Journal of Research - Granthaalayah, 6(10), 176-186. https://doi.org/10.29121/granthaalayah.v6.i10.2018.1176.

\section{Introduction}

Art has consistently played a significant role in uplifting architecture and hence giving it a new definition. From ages, art has been evolved with the evolution of architecture. They have always been interdependent on each other. In ancient times people practiced art as a tool to beautify their way of living. They illustrated paintings, motifs on their walls related to their day to day life activities. As varied types of people migrated from various regions they developed their own unique architectural style and art forms according to the needs of that place, climatic conditions of that area, availability of materials and many more factors. For example, Lipan kaam(Gujarat), Warli art (Maharashtra) etc. India's unique identity is a gift of its varied culture and traditions and varied art forms. Handicrafts of India dates back up to almost 5000 years. With a due study of some art forms, the researcher intends to analyze art forms of Nirona in particular.

Nirona is located in what is locally known as Pavarpatti region, essentially characterized as a grazing land, in Kutch. The village with a population of around 5000 people is known throughout Kutch as a pilgrimage for five of the crafts of the region, namely, Rogan, Copper Bell making, Lacquer work, weaving, and Leatherwork. At a closer observation one also finds Ahir Bharat, Bandhani and Pottery being practiced in the houses of the village. The historical value of each of 
these crafts is unique and so is the fact that they all coexisted through the history of Nirona. (University, 2014) (1) According to the current survey done by researcher population of Nirona increased to nearby 10000 people.

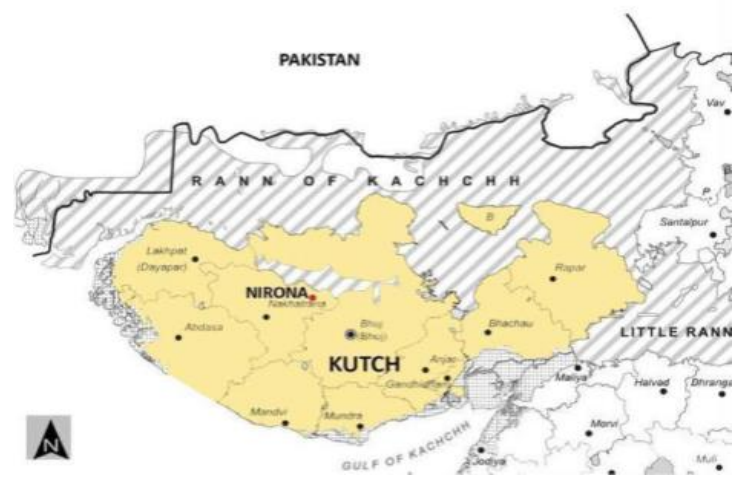

figure 1: Map of Nirona, Kutch (1)

\section{Rogan Painting}

It is a process of painting on cloth done in Kutch, Gujarat. History of Rogan dates back to 300 years ago from Persia. Earlier women from Ahir and Rabari tribe wore ghagara in their wedding but gradually it led to the restriction on a small piece of cloth. Currently, 7thand 8th generation of the family is practicing this art form. The concept of the "TREE OF LIFE" was initiated by Gaffur Bhai Khatri in 1987, inspired by stone carvings from history, which does not rely upon any castebased beliefs. "TREE OF LIFE" symbolizes freedom of life, strength and growth, prosperous future and also serves as a symbol of immortality. Six members of this family comprise of an uncle, his son and four nephews who are struggling to keep this unique art form alive. There are five women in this family involved in bandhani.

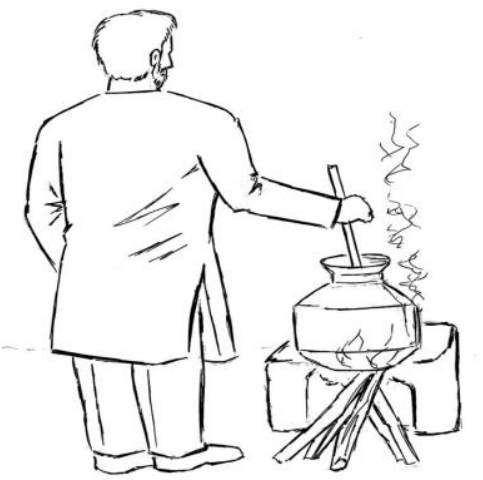

1. Castor oil burned in an aluminium container for 12 hours in a nearby forest which is $2-3 \mathrm{~km}$ far from village.

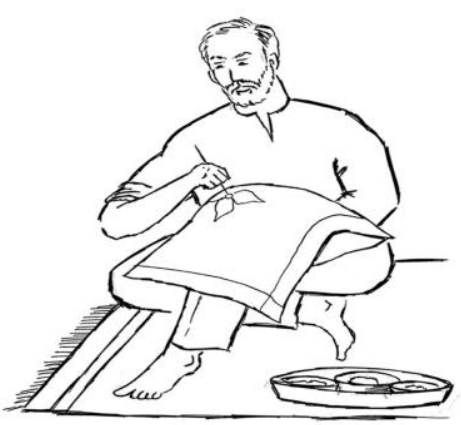

3. Designs are painted on a piece of cloth using stylus which is 6-7 inch long. Further painted cloth is folded to get symmetrical patterns.

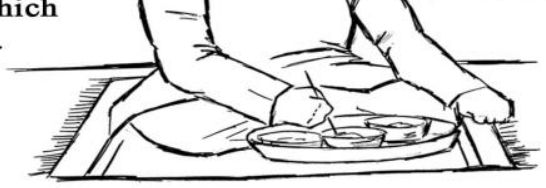

2. Pigment from ahmedabad is mixed with rogan gel and stored in a bowl containing water.

Figure 2: The process of making Rogan painting 
Further, in this research architectural spaces are documented where they perform this art:

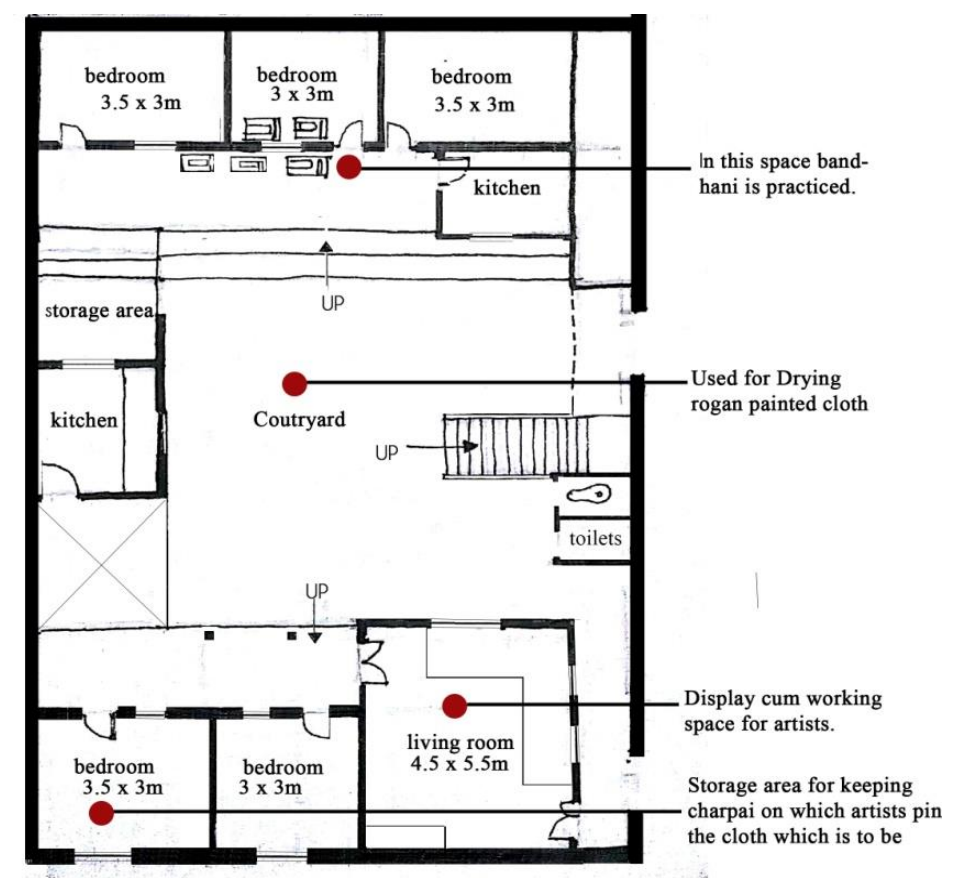

KEY PLAN

Figure 3: key plan of Rogan artist's dwelling unit.

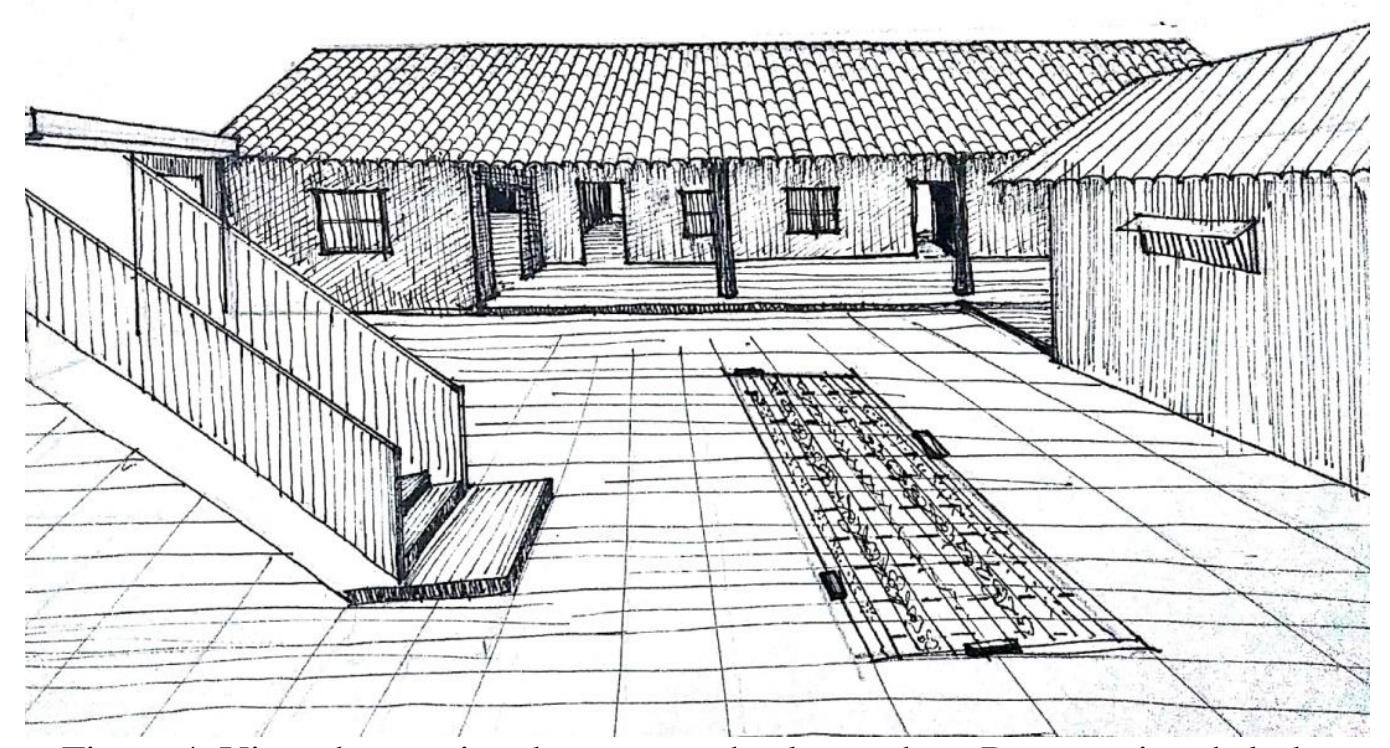

Figure 4: View showcasing the courtyard culture where Rogan painted clothes are dried.

\section{Copper Bell Making}

This art was basically originated in Angya and is almost 40 years old. The craftsmen previously resided in a nearby village called Jura and there are only two families practicing this craft in 
Nirona. Bells were used at entrances of homes and were also hung around the necks of grazing animals like cows and goats. (University, 2014)

As analyzed by the researcher, this art of bell making is unique in itself because the process involved no welding and also because of different sound produced just by hammering at different parts of the bell. There are 10 members in a family, males involved in the process of shaping the bell, baking it in the furnace and after that chipping of the fire clay, a wooden piece in the bell and finally hammering to produce different sounds. Women are involved in the process of coating the bell (the mixture of mud, kapas and copper brass zinc borax).
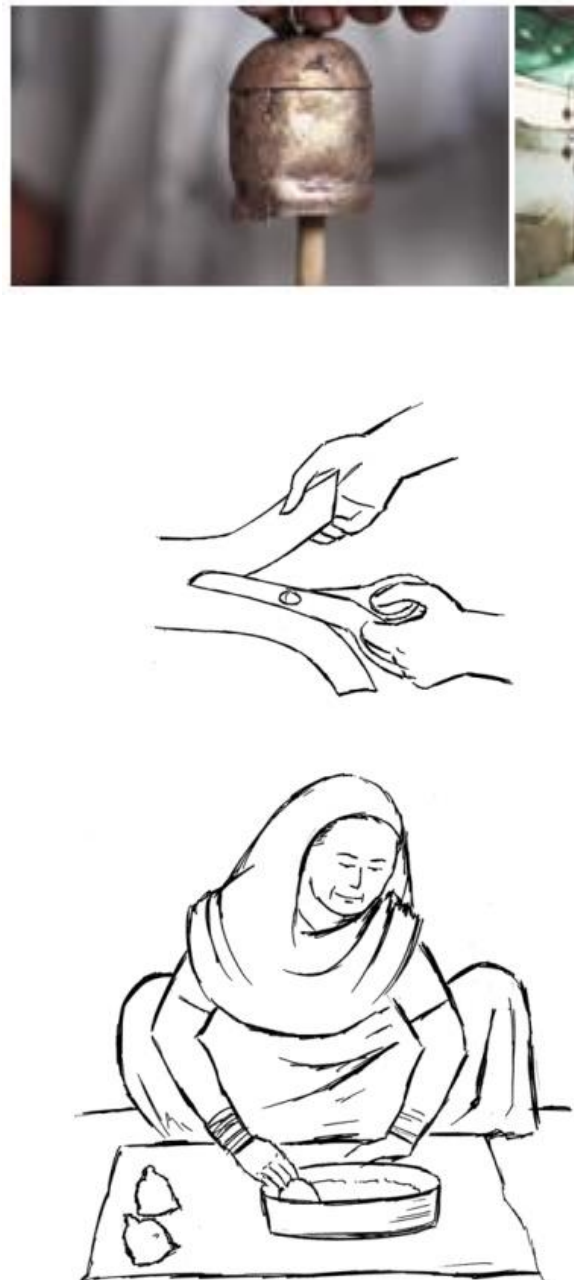

2. Bell is covered in mud and copper powder.
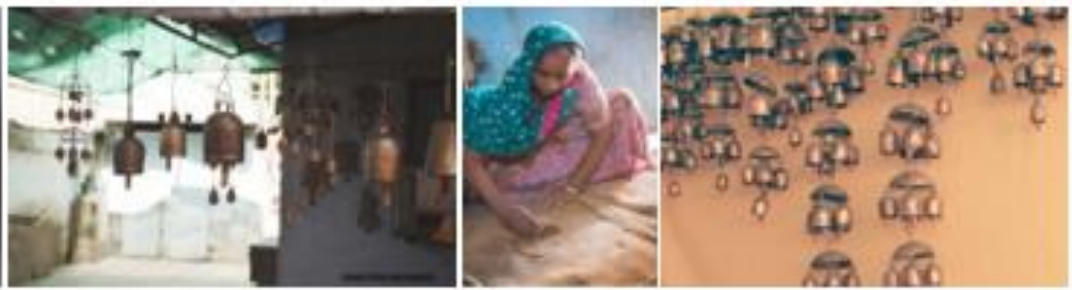

Figure 5: Copper bell

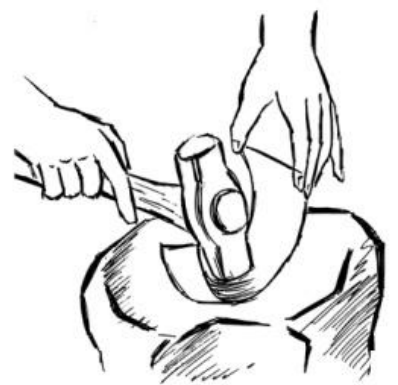

1. A bell is shaped from scrap metal.
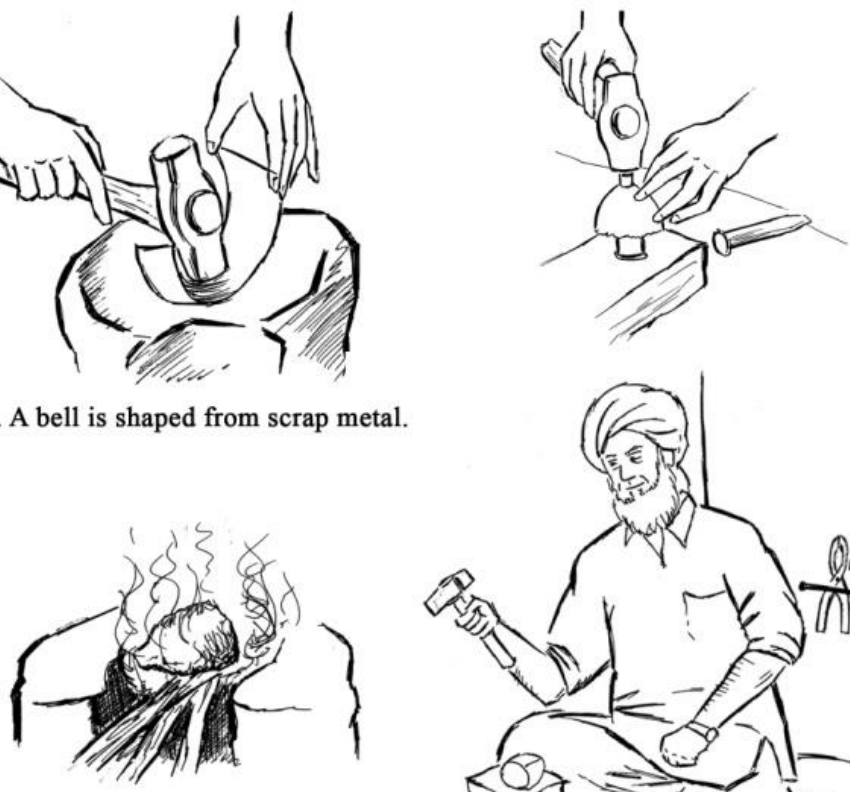

3. Baked in blast furnace

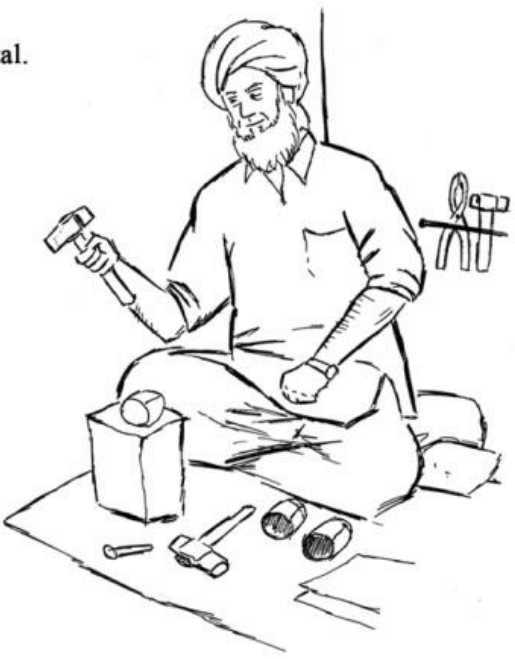

4. When the fire clay is chipped off, the bell is now revealed copperplated.. Wooden piece is inserted and then bell is hammered to produce music.

Figure 6: The process of copper bell making 
Further, in this research architectural spaces are documented where they perform this art:

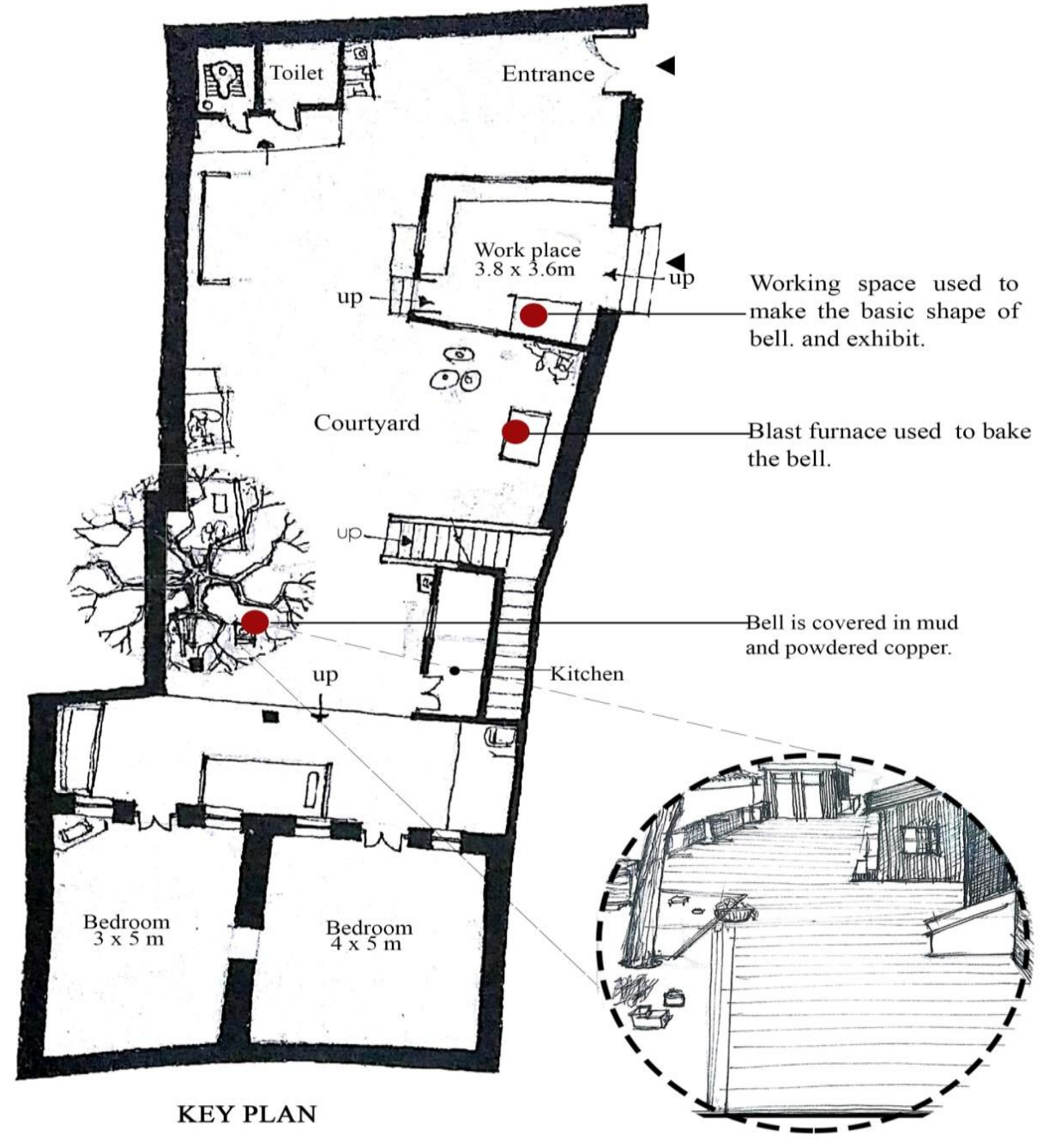

Figure 7: Key plan of Bell making community's dwelling unit.

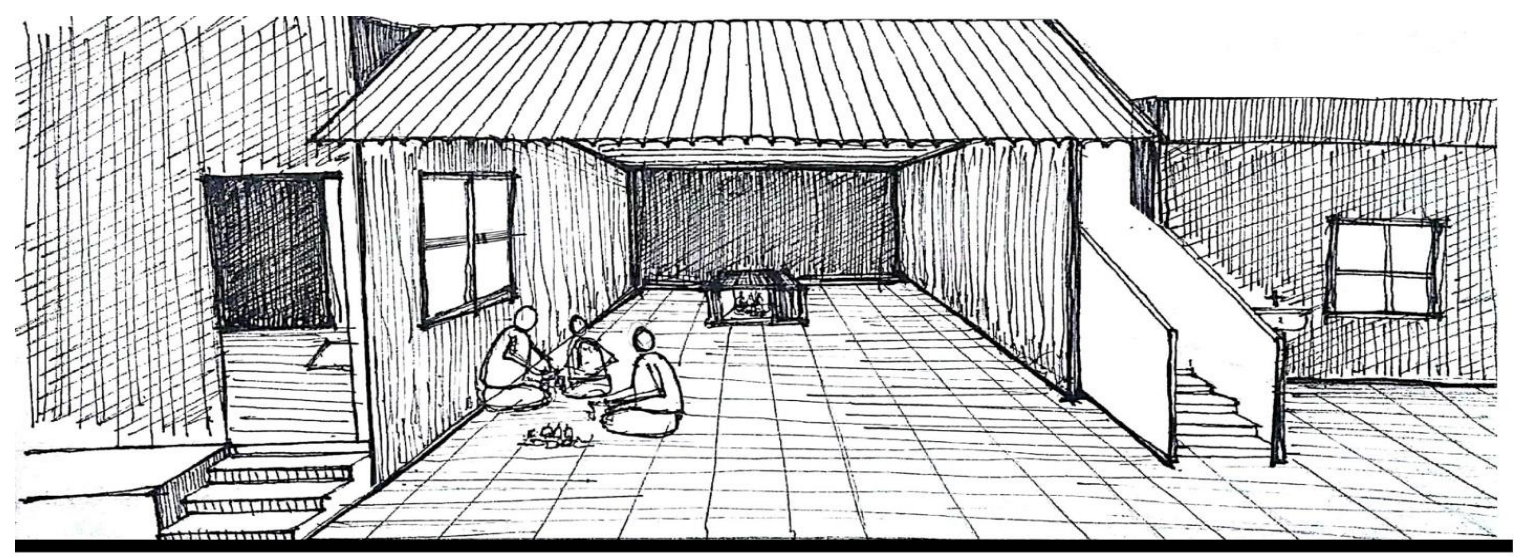

Figure 8: View of the courtyard where men are preparing copper bell and at the backblast furnace is placed. 


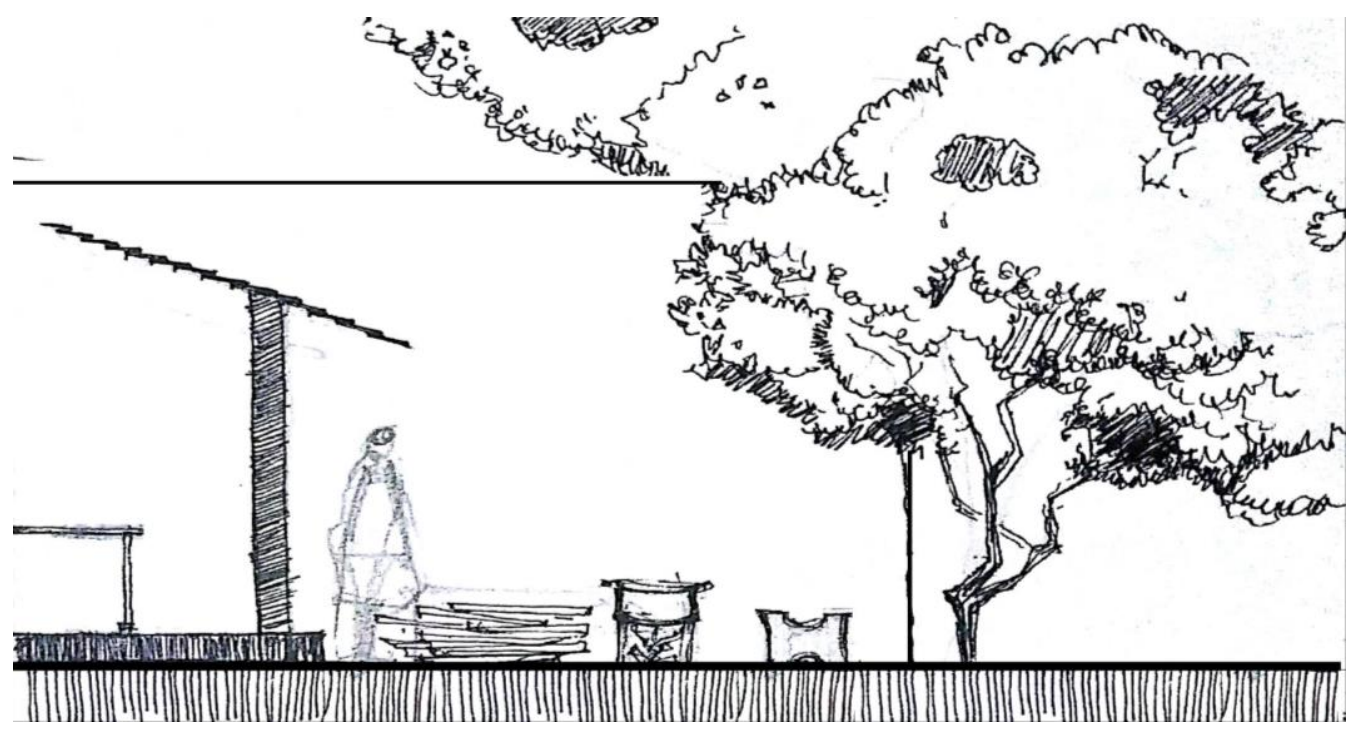

Figure 9: Section showing the area where the coating of a copper bell is done.

\section{Problems Faced by These Artists}

- They do not have certain displaying areas to exhibit their works for frequent visitors. Ran of Kutch roots the gathering of 300-400 tourists at a time who visits to have the glimpses of the artworks but these local artists do not have sufficient space to accommodate such a huge crowd.

- The artists took initiative to train girls of the village so as to involve as many people as they can and to enhance the prospects to learn these art forms, but the dynamism endured due to the unaffordability of charges.

- According to the surveys conducted, some of these artists have to travel from one place to another in order to promote their art which was not feasible according to them.

- The government provided opportunities for them to revive the cities, accordingly settle there and work, but they want urbans to visit their village and experience the dignity of their art form.

- They do not know how to compete and evolve with today's trends; they are not well versed with present marketing strategies.

- As in this village, enormous number of art forms is practiced in different areas. The distance of areas and lack of time forbids the visitors to explore each place; henceforth some of these art forms remain unraveled.

- In the process of weaving, a group of labors is required and the output is not enough for the artists to survive, so they artists are strained to switch their occupation.

- In Rogan painting, the initial process of making Rogan paste is harmful because of the fumes evolved thus only one or two man are involved in the work. They go to the outskirts of the village to initialize the work for as it is unavoidable for them to continue the same in their residential areas.

- The artists who practice the lacquer art barely know the kutchi language as well as are uneducated, which shackles the interaction between them and the visitors.

- These artists do not have any other occupation besides performing the art forms. 
- Only a particular period of the year encounters the visitors, rest of the time they are unable to attract visitors.

- Because of the demand of time, they have to use artificial raw materials as natural materials are expensive and they are not acquiring sufficient revenue by selling their products.

\section{Comparative Analysis}

\section{KHAMIR}

\begin{tabular}{|c|c|c|}
\hline Aim & Initiative & Spaces Provided \\
\hline $\begin{array}{l}\text { Khamir works to fortify and } \\
\text { promote local artists of Kutch. }\end{array}$ & $\begin{array}{l}\text { Khamir serves these artists } \\
\text { through: } \\
\text { - Social security } \\
\text { programme. } \\
\text { - Credit initiative } \\
\text { programme } \\
\text { - Raw material depot } \\
\text { - Technologies } \\
\text { - Skill development }\end{array}$ & $\begin{array}{ll}\text { - } & \text { Public workshops } \\
\text { - } & \text { Educational centers } \\
\text { - } & \text { Curated exhibitions } \\
\text { - } & \text { Research and } \\
\text { - } & \text { documentation } \\
\text { - Shops and studios }\end{array}$ \\
\hline
\end{tabular}

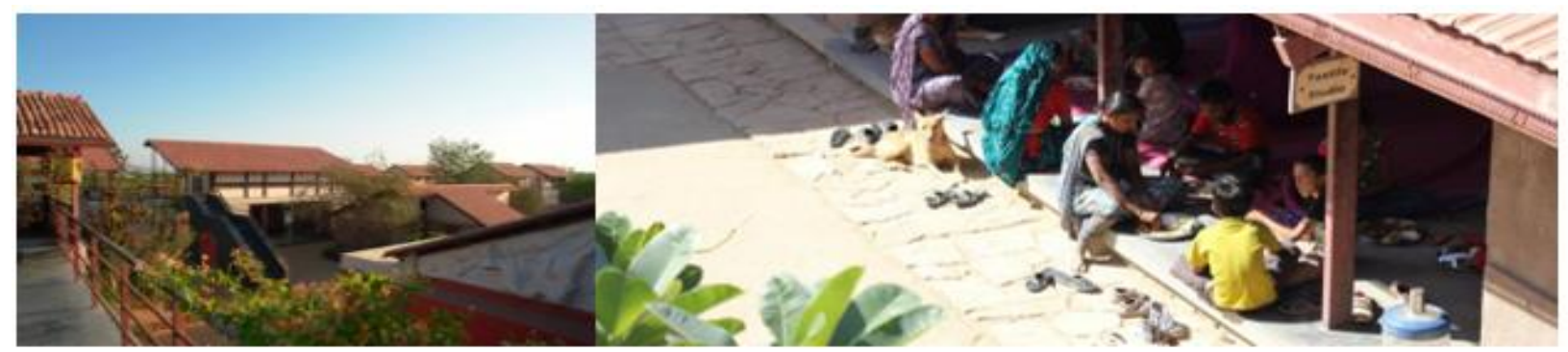

Figure 10: Khamir (3)

\section{SRUJAN (LLDC MUSEUM)}

\begin{tabular}{|c|c|c|}
\hline Aim & Initiative & Spaces Provided \\
\hline $\begin{array}{l}\text { To uphold and revitalize the craf } \\
\text { ts culture and traditions. }\end{array}$ & \begin{tabular}{|l} 
Srujan serves three categories of artists: \\
- \\
Practicing kaarigars(intensi \\
ve need-based training) \\
- Aspiring kaarigars (mentors \\
for youth) \\
- $\quad$ Rural youth (enrolled to \\
learn craft)
\end{tabular} & $\begin{array}{ll}\text { - } & \begin{array}{l}\text { Museum } \\
\text { and shops }\end{array} \\
\text { - } & \begin{array}{l}\text { Craft } \\
\text { studio }\end{array} \\
\text { - } & \begin{array}{l}\text { Auditoriu } \\
\text { m }\end{array} \\
\text { - } & \begin{array}{l}\text { Hands-on } \\
\text { gallery }\end{array}\end{array}$ \\
\hline
\end{tabular}




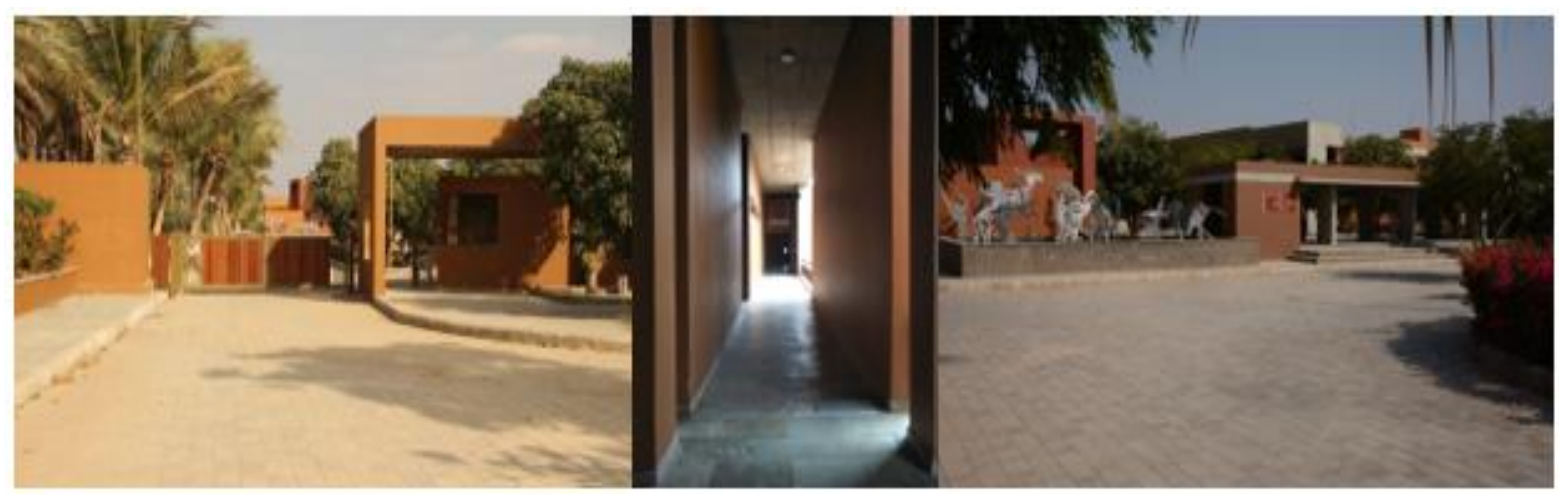

Figure 11: LLDC Museum (4)

\section{SANSKRITI KALA KENDRA}

Source: http://www.sanskritifoundation.org/kendra.htm

\begin{tabular}{|c|c|c|}
\hline Aim: & Initiative & Spaces Provided \\
\hline $\begin{array}{l}\text { To acquire a surrounding fo } \\
\mathrm{r} \text { the cultural preservation } \\
\text { and development of } \\
\text { the artistic and cultural } \\
\text { expressions of India but of } \\
\text { the world as a whole. }\end{array}$ & 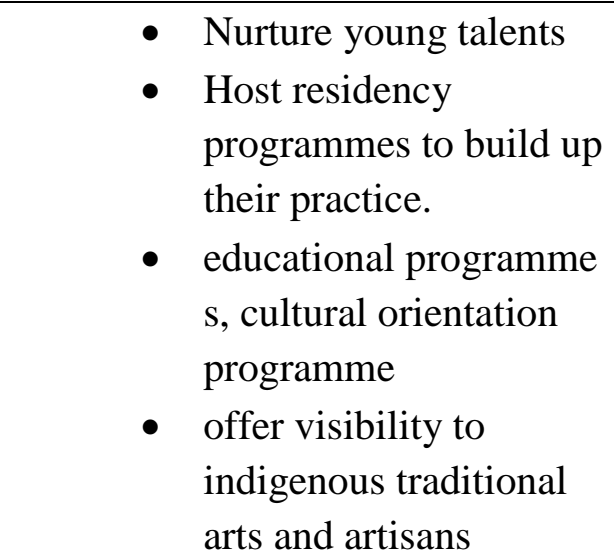 & 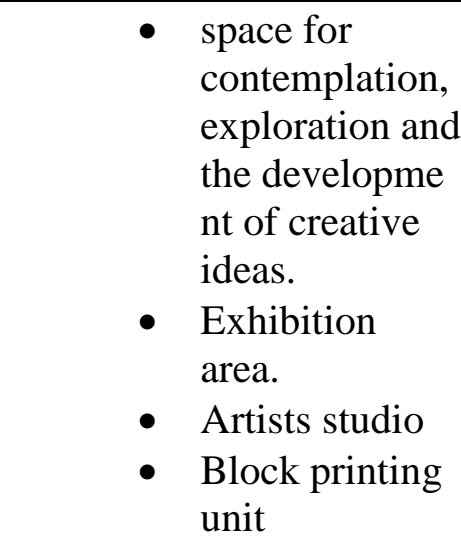 \\
\hline
\end{tabular}

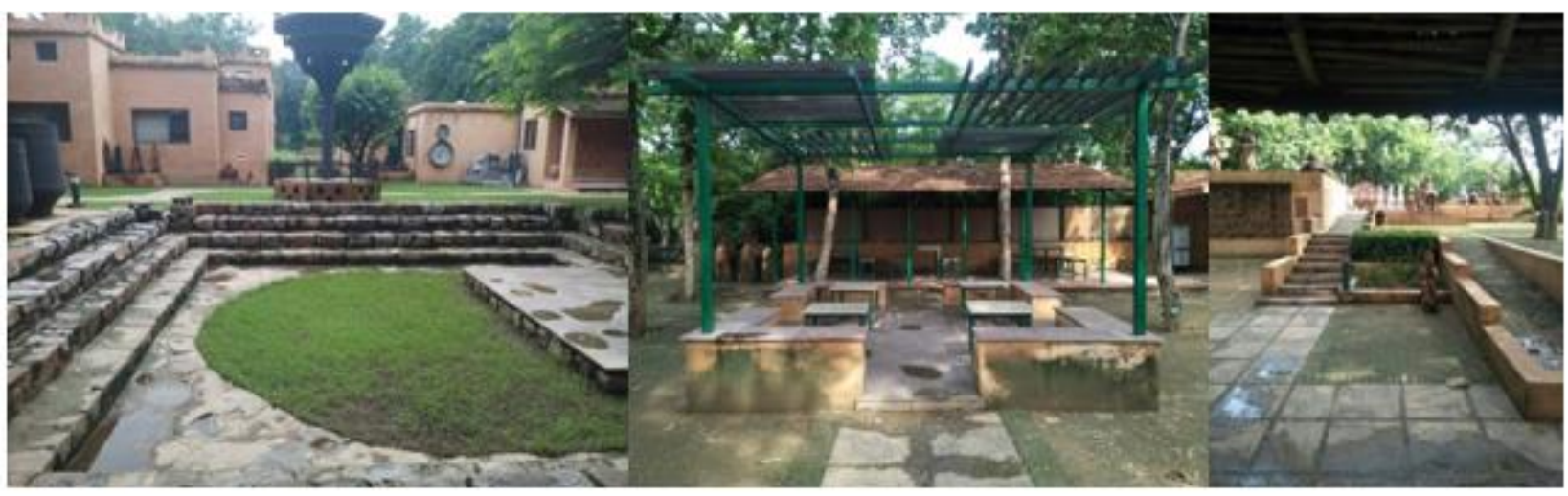

Figure 12: Sanskriti Kala Kendra 


\section{DILLI HAAT}

\begin{tabular}{|c|c|c|}
\hline Aim & Initiative & Spaces Provided \\
\hline $\begin{array}{l}\text { Dilli Haat mainly } \\
\text { promotes handicraft of } \\
\text { India, also to explore the } \\
\text { rural culture } \\
\text { and provide them with } \\
\text { spaces to exhibit their art } \\
\text { forms and sell their art } \\
\text { forms. }\end{array}$ & $\begin{array}{l}\text { Local artists from varied parts } \\
\text { of land exhibit their art and have one } \\
\text { to one social interaction with urban } \\
\text { visitors. }\end{array}$ & $\begin{array}{l}\text { Individual } \\
\text { display } \\
\text { units for } \\
\text { artists and } \\
\text { spaces for } \\
\text { group } \\
\text { discussion. }\end{array}$ \\
\hline
\end{tabular}

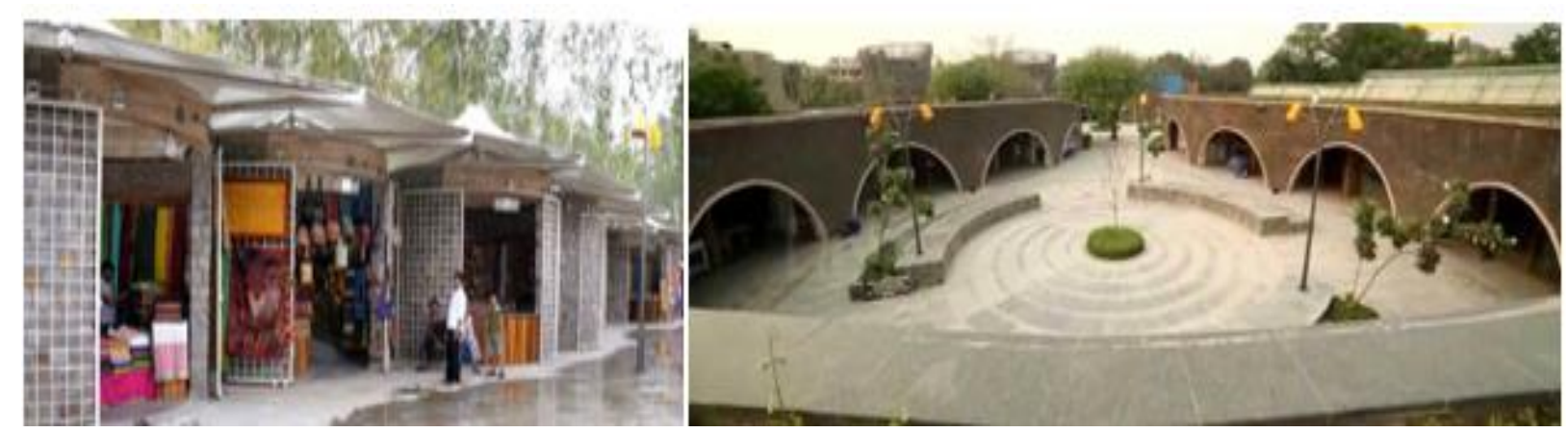

Figure 13: Dilli Haat

\section{CRAFTS MUSEUM}

\begin{tabular}{|c|c|c|}
\hline Aim & Initiative & Spaces Provided \\
\hline $\begin{array}{l}\text { This museum aims to } \\
\text { preserve the existing art and } \\
\text { crafts of India and pass it to } \\
\text { next generations to develop } \\
\text { Indian art and crafts. }\end{array}$ & $\begin{array}{l}\text { Exhibits over } 33000 \text { different } \\
\text { art forms of India over a } \\
\text { historic period of } 60 \text { years. }\end{array}$ & $\begin{array}{ll}\text { - } & \text { Art galleries } \\
\text { - } & \text { Village } \\
\text { - } & \text { Hamplex } \\
\text { - } & \text { Shops } \\
\text { - } & \text { Performing } \\
& \text { centers }\end{array}$ \\
\hline
\end{tabular}

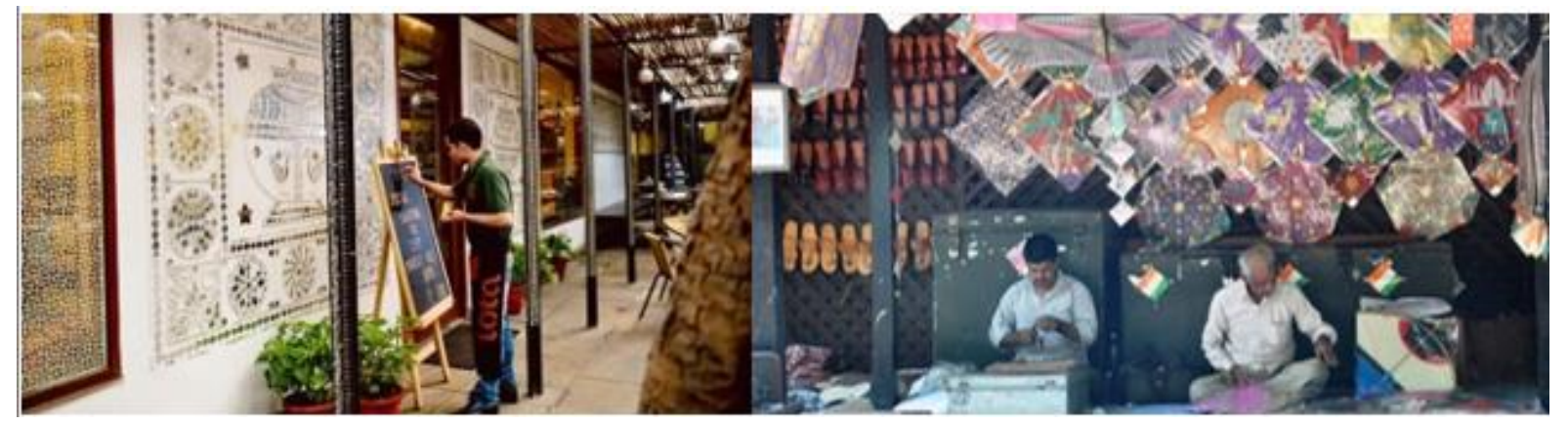

Figure 14: Craft Museum 


\section{AJRAKHPUR STUDIO}

\begin{tabular}{|l|c|c|}
\hline Aim & Initiative & Spaces Provided \\
\hline $\begin{array}{l}\text { To showcase the technique, } \\
\text { production and the art of } \\
\text { Ajrakh. }\end{array}$ & $\begin{array}{l}\text { To create a working } \\
\text { ambiance for the } \\
\text { artists and exhibition } \\
\text { spaces. Also to } \\
\text { provide artists with } \\
\text { proper } \\
\text { accommodation. }\end{array}$ & $\begin{array}{l}\text { - Craft studio } \\
\end{array}$ \\
\hline
\end{tabular}

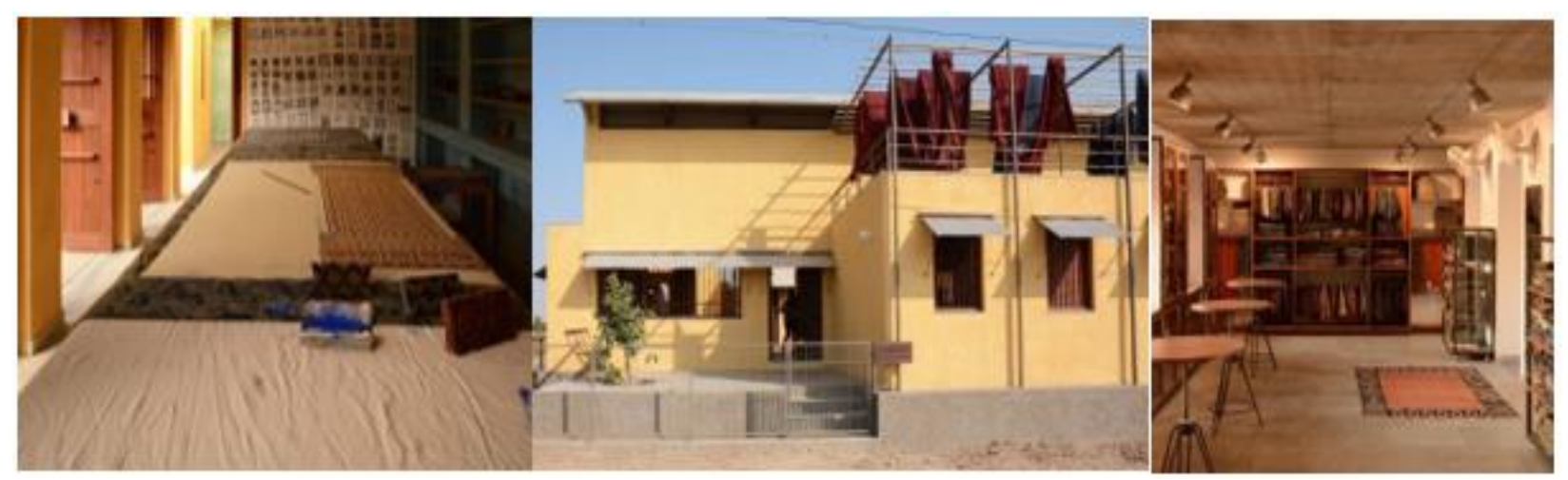

Figure 15: Ajrakhpur (10)

\section{Inferences}

- It is necessary for the artist to have direct interaction with the customers seen in DilliHaat as they are the one who knows their art the best. The motive is not just the profit but the promotion of art in the right way and right knowledge.

- Artists are emotionally rooted in the place where they learned an art and are comfortable to practice in. Therefore, switching them to urban areas has no point for their establishment. This is the major problem artists are facing today, struggling to keep their art and culture alive.

- These artists should be financially supported as their economic conditions are not good, ultimately forcing themselves to switch from their ancestral way of earnings.

- $\quad$ As analyzed in the LLDC museum, Spaces should be provided where local people can also feel free to learn the art. This is the way by which any art can be explored and it can flourish.

- $\quad$ Spaces should be provided such that it accommodates visitors and artists together, so that visitors could learn and experience the lifestyle of artists and feel connected to our culture, as seen in Sanskrit Kala Kendra.

\section{Conclusion}

The researcher has concluded from literature reviews and visiting various places that, Architectural spaces should be provided as a solution to many of the identified problems faced by the artist. 
Workshops and training centers should be provided, that can help to flourish their art, exhibition area and shops should be provided with one to one interaction with the artist that will help the visitors to understand the importance of art while experiencing it. Audiovisual rooms should be provided that will help the people to understand the art in detail. Hands on galleries should be provided so that people can experience the art while performing it. Learning center should be provided for the artist to learn business parameters and personality development. Their dwelling units could be designed to provide a proper working area.

\section{Acknowledgement}

First of all, I would like to express my gratitude towards my guide Ar. Soma A Mishra who helped me throughout my research in all possible ways she could. Also to my dissertation head Er. Utkarsh Jain, dissertation sub-head Ar. Khushboo Lahori for their presence. I would like to offer my sincere thanks to all the faculty members, seniors and colleagues who directly or indirectly encouraged and helped me. I am grateful towards the local artists and their family of Nirona who cooperated with me during my research. To all the NGO's and people who provided me with appropriate data needed for my documentation. Finally, I would like to express my gratitude to my family, for their unconditional support and prayers at all time and constant encouragement during the entire course of my dissertation work.

\section{References}

[1] https://portfolio.cept.ac.in/wp-content/uploads/2014/11/Designing-With-People.compressed.pdf

[2] http://www.isca.in/FAMILY_SCI/Archive/v2/i1/1.ISCA-RJFCCS-2013-026.pdf

[3] http://www.khamir.org/

[4] http://indigo-architects.com/project/lldc/

[5] http://www.craftmark.org/sites/default/files/Copper\%20Bell\%20Craft.pdf

[6] http://www.niscair.res.in/sciencecommunication/ResearchJournals/rejour/ijtk/Fulltextsearch/2010 /October\%202010/IJTK-Vol\%209(4)-October\%202010-pp\%20644-650.htm

[7] Ranjan Aditi, (2009.) Handmade in India. Map in Publishing

[8] http://www.sanskritifoundation.org/kendra.htm

[9] https://www.archdaily.com/777641/dilli-haat-archohm-consults

[10] http://indigo-architects.com/project/ajrakh_studio/

[11] http://nationalcraftsmuseum.nic.in/?page_id=6

\section{All the sketches are handmade by the main author.}

\footnotetext{
*Corresponding author.

E-mail address: sejalselwadiya12@gmail.com
} 